\title{
O Borges DESTA AMÉricA E OUTRAS PERSONAS LITERÁRIAS
}

\author{
Livia Grotto \\ liviagrotto@gmail.com
}

No poema "Mis libros", publicado em 1975 no livro La rosa profunda, o eu lírico, confrontado com o que crê de fato expressá-lo, confessa-se com um duplo sentimento. Amargura, pois as palavras essenciais encontrar-se-iam na obra de outros, ealguma satisfação, por saber-se eternamente reconhecido na voz de escritores mortos. Ao anúncio desse duplo sentimento, o eu lírico antepõe uma equivalência, porque sente que a pertença de si dá-se tanto através dos livros - discretamente humanizados por não saberem de sua existência - quanto através de seu gesto, cujo olhar esvaecido se acompanha das mãos para só então reconhecer o próprio rosto. Curiosamente, o Borges cego e envelhecido - com olhos e têmporas cinzas - retira-se, assim, como escritor, para dar-se a conhecer como leitor. O título do poema afigura-se traiçoeiro; os "meus" não se referem aos livros que escreveu, mas aos que leu:

\footnotetext{
Mis libros (que no saben que yo existo) son tan parte de mí como este rostro de sienes grises y de grises ojos que vanamente busco en los cristales y que recorro con la mano cóncava. No sin alguna lógica amargura pienso que las palabras esenciales que me expresan están en esas hojas que no saben quién soy, no en las que he escrito. Mejor así. Las voces de los muertos me dirán para siempre (BORGES, 2011, p. 152).
} 
Essa dissolução do lugar enunciativo do escritor caracteriza outros textos do autor, como o conto "El otro" de El libro de arena, o poema em prosa "Borges y yo" de El hacedor, o famoso "Pierre Menard, autor del Quijote" de El jardín de senderos que se bifurcan ou um dos ensaios de juventude de Inquisiciones, "La nadería de la personalidad”. Também está nos prefácios de Historia universal de la infamia. No primeiro deles, por exemplo, um Borges aparentemente despretensioso escreve influenciado pelas obras de Chesterton e de Stevenson, também pelos filmes de von Sternberg.

Ao longo do tempo, as posturas fixadas em prefácios como esses, nos livros em geral, nas revistas, entrevistas e aparições públicas, definiram a figura do escritor que hoje conhecemos: discreto e culto, que observa o mundo pelo prisma dos inúmeros livros, cujas leituras (silenciosas) ele pôde acumular até meados da década de 1950. Seria cômodo, portanto, reencontrar em Historia universal essa imagem, tão estanque. Ela foi muitas vezes retomada pela crítica e pelas histórias literárias, por vezes pouco vigilantes com relação ao artifício desse escritor, por vezes interessadas em resumos didáticos.

Tendo em conta que ao longo de Historia universal o escritor não se preocupa em distinguir-se de seus narradores: seja fisicamente, moralmente, intelectualmente ou temporalmente, para que se retome aqui o estudo inaugural de Wayne Booth (1996) sobre o ponto de vista e a voz narrativa, este ensaio tem como meta observar os percursos da voz narrativa e suas implicações sobre a imagem do autor implícito. A confusão das instâncias autoral e narrativa ocorre desde os prefácios.

\section{LIMIARES}

No livro Seuils, Genette (1987) dedica três capítulos ao estudo do prólogo ou prefácio, considerando-o um espaço paratextual, de entrada para o texto que se segue. O título escolhido para seu estudo é extremamente produtivo para descrever os prólogos de Historia universal. "Seuil" é a soleira de uma casa, limiar entre o interior e o exterior. Mais do que a entrada, é a fronteira entre o mundo do leitor e o mundo do livro, entre a vida e a imaginação. Um passo para fora e já não há ficção, um passo para dentro e é impossível reencontrar o mundo conhecido como real. Na soleira os limites aparecem confundidos. Essa confusão caracteriza, 
além disso, a voz daquele que, nos prólogos, endereça-se ao leitor com a finalidade de assegurar uma boa leitura para a Historia universal.

Ainda segundo Genette, entre os tipos de prólogo existentes, encontrar-se-iam o autoral, feito pelo próprio escritor, o alógrafo, escrito por alguém que fala por ele, e o ficcional, redigido por um dos personagens. Em Historia universal, ao perguntarmos pelo "quem?" concluímos rapidamente que os prólogos são autorais. Os dois estão assinados com as iniciais de Jorge Luis Borges.

Com as três primeiras possibilidades de prólogo, Genette entrecruza outras três: é autêntico quando atribuído a uma pessoa real, fictício se o responsável é um autor imaginário ou um personagem, e apócrifo, quando um ou mais índices vêm colocar em dúvida a realidade do que é afirmado. Segundo Genette (1987, p. 177), a configuração de um prólogo simultaneamente autoral e apócrifo existiria nada mais do que a título “teórico" e "provisório", por falta de exemplos que possam atestá-la. No caso de Borges, os prólogos, desprovidos de atribuições fantásticas, são autorais e autênticos. Apesar disso, constroem uma figuração dupla e ambígua, a do autor e narrador de Historia universal de la infamia.

\section{Os prólogos e as personas de Borges}

Nos prólogos, J.L.B. busca um favor afetivo, fazendo uso da captatio benevolentiae. Assim, eles rebaixam o autor para conseguir a indulgência do leitor. No primeiro, de 1935, os contos de Historia universal não passariam de "ejercicios de prosa narrativa" e a parte chamada "Etcétera" seria composta por textos sobre os quais seus únicos direitos seriam os de tradutor e de leitor (BORGES, 2009, s.p.). Dezenove anos depois, essa mescla de autocrítica e de baixa autoestima retorna. No prólogo de 1954, os contos são, então, o resultado do "juego irresponsable de un tímido" que construiu "ambiguos ejercicios", hesitando entre o desejo de criar composições próprias ou reescrever histórias alheias. Além disso, num tom menor, J.L.B. adverte o sofrimento do homem que ao transportar-se para o espaço livresco pôde divertir-se narrando: "El hombre que lo ejecutó era asaz desdichado, pero se entretuvo escribiéndolo". Humano e frágil, o autor implícito ganha a complacência do leitor ao confinar-se na condição de sofredor e de iniciante.

Em 1935, resumindo sua genealogia - se bem que dissimulada por um "tal vez" -, J.L.B. soma um livro de sua autoria à fonte dos "exercícios 
narrativos". Nesse ponto, os senões começam a minar a estabilidade interpretativa do prólogo. Os contos apresentados, segundo J.L.B., "Derivan, creo, de mis relecturas de Stevenson y de Chesterton y aun de los primeros films de von Sternberg y tal vez de cierta biografía de Evaristo Carriego". A mesma medida de indecisão pauta as menções ao Evaristo Carriego de Borges e aos outros três artistas, todas dispensadas depois de um "talvez" ou de um "creio". As incertezas de J.L.B. germinam, então, as do leitor.

Evaristo Carriego, publicado em 1930, foi o primeiro estudo inspirado no poeta popular, vizinho e frequentador da família Borges. Carriego publicara somente um livro de poemas em vida, Misas herejes, e seu gosto pelos dramas sentimentais e cotidianos - dos ladrões, prostitutas, valentões e de trabalhadores pobres como a "costurerita que dio aquel mal paso" (BORGES, 2009, p. 244) - ensejaram em Borges a continuidade de um projeto de estetização do infame que culminaria em Historia universal de la infamia, tendo começado timidamente, a partir das margens, daí o subúrbio de Buenos Aires, contemplado em seus três primeiros livros de poemas: Fervor de Buenos Aires, Luna de enfrente e Cuaderno San Martín.

No livro Evaristo Carriego, Borges primeiro discorreria sobre o ambiente marginal do bairro de Palermo, sobre o rio Maldonado, pantanoso e logo encoberto, os arredores da antiga penitenciária da avenida Las Heras, os armazéns onde os homens bebem e por vezes matam. No segundo capítulo, recupera o "talvez esquecido" Evaristo Carriego, poeta menor, com seu gosto pelos pátios da vizinhança, pelos velórios, os lugares de perdição e o hospital, também pelas "puñaladas de bailecito y de esquina", pelos "hombres de la esquina rosada" (BORGES, 2009, p. 224, 228). Evaristo Carriego, lembra Borges, era amigo do caudilho de Palermo Nicolás Paredes: é certo que escrevia poemas, completa o autor, mas tratava de igual para igual com assassinos. Nos capítulos três e quatro desse livro de ensaios, Borges comenta os poemas desse escritor-valentão, demonstrando que, como seu objeto de estudo, também domina o tema das margens e do marginal. Faz uma apreciação, por exemplo, do poema "El guapo"/ "O valentão" de Misas herejes e escreve uma extensa nota de rodapé na qual distingue entre "paisano", "gaucho", "compadrito" e "guarango".

No prólogo de Historia universal, a referência tingida de modéstia a “certa biografia de Evaristo Carriego" tenciona um leitor que a conheça. Ou que desde antes de ingressar nas histórias infames sinta-se levemente 
excluído do círculo pretendido de leitores, embaraçado por ignorar aquilo que, segundo o autor, parece ter valor e peso semelhantes aos de Stevenson, Chesterton e von Sternberg.

Esse desconforto pode aumentar algumas linhas depois, com o surgimento de outra frase dubitativa: "A veces creo que los buenos lectores son cisnes aún más tenebrosos y singulares que los buenos autores”. A incerteza do "às vezes creio" não impede a comprovação da hipótese, de imediato explicitada. O tom seguro contrasta, então, com as hesitações anteriores: "Nadie me negará que las piezas atribuidas por Valéry a su pluscuamperfecto Edmond Teste valen notoriamente menos que las de su esposa y amigos”. A comprovação de que os bons leitores são ainda mais "tenebrosos" e "singulares" do que os bons autores é corporificada na esposa e nos amigos do personagem Edmond Teste. Comparados com esse gênio incomunicável imaginado por Valéry - um irônico "mais-que-perfeito" segundo J.L.B. -, sua esposa e amigos teriam maior capacidade para transformar simbolicamente o que observam ou, em outras palavras, seriam melhores leitores do que Edmond Teste. Efetivamente, e por isso J.L.B. afirma que "ninguém pode negar" essa conclusão, o quase inumano Teste reflete sobre o mundo e a humanidade sem que para isso leia ou escreva. Pela segunda vez, solicita-se em Historia universal um leitor que compartilhe as leituras de J.L.B. a fim de seguir suas afirmações sem sentir-se excluído desse mundo livresco, fortemente instituído desde o prefácio.

A frase final desse primeiro limiar do livro vem exaltar de uma vez por todas a leitura como tarefa: "Leer, por lo pronto, es una actividad posterior a la de escribir: más resignada, más civil, más intelectual”. Nesse ponto, o leitor experimenta um forte apelo às suas capacidades, pois J.L.B. despeja-lhe uma obrigação. Sem autorização para errar, deve equilibrar o que lê com resignação, civilidade e cultura, superando, como a mulher e os amigos de Edmond Teste, o papel do bom autor.

Uma das maiores contribuições de Borges para a reflexão da crítica literária, desde o interior da literatura, está nessa noção de que o ato de leitura éo quedefinea qualidade do literário. Masa sombra desse leitor ideal e extremamente ativo, que contribui para o livro e enriquece-o, constrói, na realidade, um leitor efetivo paralisado pelo excesso de expectativas. Genette (1992, p. 375) caracterizaria essa forma de introdução ao texto que se segue como uma "força de intimidação hermenêutica".

As frases de J.L.B., são, no entanto, tão ambíguas e têm tão poucos encadeamentos que permitem compreender, em outro sentido, que é 
ele próprio o leitor comparável a um cisne negro, maior em trevas e em singularidade do que qualquer bom autor. Recorde-se, a esse propósito, que nas primeiras linhas desse prólogo de 1935 ele se apresenta como um leitor da seção "Etcétera”.

\section{Barroco e barroquismos}

A expressão utilizada por J.L.B. no prólogo de 1954, “ambíguos exercícios", reforça o alerta para as dubiedades levantadas em 1935. Mas quase vinte anos depois da primeira edição de Historia universal, é verdade que esse J.L.B. está mais próximo do Borges de 1955, diretor da Biblioteca Nacional argentina e membro da Academia Argentina de Letras, assim como do Borges de 1956, Professor da Cátedra de Literatura Inglesa da Universidad de Buenos Aires e ganhador do Premio Nacional de Literatura.

O texto do prólogo de 1954 se inicia com uma definição professoral do estilo barroco fornecida, entretanto, por um "yo diría" - que tornará a repetir -, marca de elegância na medida em que enfraquece o "eu", mas também de desvio da responsabilidade com relação à informação: "Yo diría que barroco es aquel estilo que deliberadamente agota (o quiere agotar) sus posibilidades y que linda con su propia caricatura”. Mais à frente, a definição se expande:

Barroco (Baroco) es el nombre de uno de los modos del silogismo; el siglo XVIII lo aplicó a determinados abusos de la arquitectura y de la pintura del XVII; yo diría que es barroca la etapa final de todo arte, cuando éste exhibe y dilapida sus medios [...]

Ya el excesivo título de estas páginas proclama su naturaleza barroca.

De acordo com o excerto, o barroco, considerado sem rigor histórico, não se restringe a uma época, mas é um estilo que determina o final de qualquer evolução artística, seja no campo da arquitetura, da pintura ou como destacaria J.L.B. tomando-se como exemplo - no campo da escrita de "Histórias universais". Acima, na última frase do excerto, ele afirma que desde o título a Historia universal de la infamia proclama-se de "natureza barroca”. Incita, desse modo, à polêmica, pois sem explicar ou argumentar, deixa que o leitor subentenda que seu próprio livro representa o ponto final da arte de compor "Histórias universais", sendo, portanto, o ápice do gênero. Em outras palavras, a Historia universal marcaria o momento em que a curva até então ascendente passa pelo cume, sempre barroquista: 
depois dela a curva só decresceria, indo de encontro à morte do gênero "História universal", pois todas as possibilidades de inovação teriam se esgotado.

Em 1921, os leitores da revista Nosotros de Buenos Aires puderam testemunhar uma impugnação desse tipo, embora mais claramente exteriorizada. Era realizada pelo jovem Borges, de volta ao país natal, mas ainda carregado da experiência vanguardista da qual participara ativamente na Espanha. Decretava, então, os estertores do modernismo de Rubén Darío: "el rubenianismo se halla a las once y tres cuartos de su vida, con las pruebas terminadas para esqueleto". Borges (1997) propunha, em seu lugar, a estética ultraísta, em várias oportunidades descrita como barroca. Exemplificava-a com poemas de ilustres desconhecidos, ao menos para os leitores argentinos da época: os espanhóis Pedro Garfias, Gerardo Diego, Heliodoro Puche e Ernesto López-Parra, além de seu primo, o imberbe poeta Guillermo Juan.

No prólogo de 1954 à Historia universal, embora seja discreto, J.L.B. mede-se com escritores universalmente conhecidos. Guarnecido das volutas barrocas, e sem abordar diretamente sua própria posição no panorama sugerido, deixa que o leitor descubra nas entrelinhas do excerto a seguir que concorda com Bernard Shaw quando este afirma que "todo trabalho intelectual é humorístico", e que comete "abusos” parecidos, nada menos, com os que praticaram os escritores barrocos Baltasar Gracián e John Donne. Ao leitor, parece insinuar J.L.B., caberia a tarefa de encontrar onde está o humor de seu "trabalho intelectual", assim como julgar qual é o "abuso" barroco cometido pela Historia universal de la infamia. Encoberto pela modéstia, J.L.B. instala-se, dessa forma, na plêiade dos melhores e ilustres: "El barroquismo es intelectual y Bernard Shaw ha declarado que toda labor intelectual es humorística. Este humorismo es involuntario en la obra de Baltasar Gracián; voluntario o consentido, en la de John Donne”.

Nesse livro que viria encerrar todo um ciclo de "Histórias universais", a desagregação de todo e qualquer sentido já estava em marcha. Com seu estilo simultaneamente afirmativo e dubitativo, J.L.B. refere-se à "vacuidade" de sentido, determinado a contrariar, desde as soleiras da Historia universal de la infamia, as expectativas do leitor. Talvez, avalia no prólogo de 1954, os doutores do budismo maaiana não tenham razão no resto, mas no que concerne a seu livro estão corretos: "o essencial do universo é a vacuidade". 
Junto dessa conclusão radical e pouco auspiciosa, entra em funcionamento um mecanismo, acionado em mais de uma oportunidade (como numa comparação entre Andrew Lang e Alexander Pope, à qual retornaremos mais tarde). Trata-se da injúria a outrem (seja ele um escritor, um livro, uma tradução, ou, neste caso, uma filosofia) com a finalidade de autoelogiar-se. Assim, a captatio benevolentiae de J.L.B. denigre apenas parcialmente o livro que apresenta, pois é o alcance da filosofia conhecida como o "Grande Veículo" que sofre, ironicamente, uma restrição violenta. Apesar da "vacuidade" e do "nada", na Historia universal de la infamia permanece intocada a capacidade de causar tumulto e o título, de aturdir:

\footnotetext{
Los doctores del Gran Vehículo enseñan que lo esencial del universo es la vacuidad.

Tienen plena razón en lo referente a esa mínima parte del universo que es este libro.

Patíbulos y piratas lo pueblan y la palabra infamia aturde en el título, pero bajo los tumultos no hay nada. No es otra cosa que apariencia, que una superficie de imágenes; por eso mismo puede acaso agradar.
}

A apatia do homem de 1954 - cansado da "aparência" e do "nada" - esconde o jovem iniciante de 1935, mas as travessuras prosseguem. Depois de tantas, não parecerá demasiado notar que no segundo prólogo J.L.B. recorda o sucesso do conto "Hombre de la esquina rosada" e apesar disso afirma não tê-lo assinado, senão com o nome de um antepassado, “abuelo de sus abuelos". Esse índice de humildade não se confirma tal qual e a modéstia é falsa, como em outras ocasiões. J.L.B. finge esconder-se detrás de Francisco Bustos, seu tataravô, mas esse nome não figura em nenhuma das edições de Historia universal de la infamia. Se houve uma despersonalização do Borges-autor através desse pseudônimo, ela ocorreu somente numa das versões desse conto, quando foi intitulado "Hombres de las orillas" e publicado na "Revista Multicolor de los sábados" do jornal Crítica, número 6, em 16 de setembro de 1933. J.L.B. recorda - certamente uma das possibilidades do prólogo autoral e autêntico de Genette - mas também omite.

É categórico, além disso, ainda que as asseverações sejam posteriormente contraditas por passagens importantes dos contos de Historia universal de la infamia. Em 1935, por exemplo, almeja direcionar a leitura do livro e assegura que este não apresenta uma abordagem psicológica. Mas acaso o leitor ignorará a rememoração feita pelo personagem de "Hombre de la esquina rosada", emocionado com sua 
valentia de antanho e dividindo com os ouvintes o momento em que abandonou a insignificância e o anonimato? Poderá esquecer a meditação que absorve a viúva Ching antes de render-se à esquadra imperial? Deixará de perceber a curiosa hesitação de Bogle ao atravessar a rua? Apagará as versões contraditórias das falcatruas de Tom Castro, signos de seu desejo de agradar e de sua instabilidade psicológica?

Outras vezes, J.L.B. induz ao erro. Ao afirmar que a seção "Etcétera" contém traduções, engana o leitor, uma vez que "El brujo postergado", pertencente a esse conjunto, não é uma tradução em sentido estrito, mas a reescrita e atualização do castelhano antigo de um dos contos de $E l$ conde Lucanor. Trata-se, segundo o vocabulário do J.L.B. de 1935, de "uma leitura singular" e quem sabe "tenebrosa", razão pela qual se apresentava desde o primeiro prólogo como um "leitor" dos contos de "Etcétera".

Nesse mesmo campo da imprecisão traiçoeira, a última frase do prólogo de 1954 sustenta que três novas "peças" foram incluídas na seção de traduções. Duas delas, no entanto, são de sua própria autoria: "El enemigo generoso" e "Del rigor en la ciencia". O uso informal que se faz no Brasil da palavra "peça” e a expressão "pregar uma peça” podem ajudar a dirimir o gracejo. J.L.B. não discorre sobre seu livro somente a partir da condição de autor, mas igualmente a partir do ponto de vista de um narrador que redige suas próprias leituras. Um autor, narrador e leitor pouco confiável, diga-se de passagem.

Finalmente, J.L.B. pode ser bastante elíptico. É o que ocorre quando explica o estilo barroco a partir de Andrew Lang e Alexander Pope, citados segundo aquele mecanismo que abordamos antes, responsável, neste caso, por denegrir esses autores com a finalidade de autoelogiar-se. "En vano" - afirma J.L.B. - "quiso remedar Andrew Lang [...] la Odisea de Pope; la obra ya era su parodia y el parodista no pudo exagerar su tensión”. Apesar de pretender didatismo, a frase é obscura, pois nela o assunto principal, ou seja, o barroco, está razoavelmente deslocado. Por outro lado, uma vez que o leitor reconheça que J.L.B. compara traduções e tradutores da Odisseia, chamando a tradução de "paródia" e o tradutor de "parodiador", a frase torna-se ainda mais insólita. Primeiro porque, sem nenhum tipo de arcabouço argumentativo, é inusitado que traduções exemplifiquem procedimentos de uma corrente estético-literária; segundo, porque atribui um valor positivo para a tradução de Pope, tratada como uma paródia. Mais do que uma explicação a respeito do barroco, a releitura das traduções para o inglês da Odisseia volta a reivindicar para J.L.B., desta vez 
segundo o viés de "tradutor" da seção "Etcétera”, um lugar dentro da alta tradição letrada, comparável, nada menos, com o ocupado pela tradução de Pope. ${ }^{1}$

Nos prólogos de 1935 e de 1954, Borges atua em seu novo papel, pois Historia universal de la infamia lança-o como narrador. Excluídas, portanto, as publicações do jornal Crítica, no qual quase todos os textos foram publicados em primeira mão, o jovem escritor era até então conhecido somente como poeta e, em menor escala, como crítico e ensaísta. Mesmo como poeta, não tinha fama. Em entrevistas posteriores, contaria em tom de anedota que reservara uma parte dos trezentos exemplares da primeira edição de Fervor de Buenos Aires. Com eles, foi até a revista Nosotros, pedindo a um de seus diretores que deslizasse, gratuitamente, um exemplar para cada bolso dos paletós que circulavam por lá.

\section{Ombro a ombro com o narrador: Borges em "Hombre de la esquina rosada"}

O livro de Borges tem ainda outras fronteiras textuais inusitadas, em que a voz narrativa se imiscui, insidiosa e ambígua. Assim, antes de avançar em uma reflexão sobre a voz narrativa dos contos infames, este ensaio detém-se em outra soleira da Historia universal de la infamia: "Hombre de la esquina rosada". Mesmo graficamente, este conto, assim como a seção de traduções "Etcétera" e a bibliografia intitulada "Índice de las fuentes" constituem instâncias separadas, formando a sequência final do livro. No sumário da edição de 1935, o tamanho das fontes chega a demarcar esses limiares textuais, apartando-os claramente do prólogo, assim como do núcleo que empresta seu nome ao livro de Borges, "Historia universal de la infamia”.

Segundo o prólogo de 1954 da Historia universal, "Hombre de la esquina rosada” é uma exceção. Além de ter obtido sucesso, é um "conto direto", escrito sem o apoio de leituras ou releituras. Longe, portanto, de uma repetição, o conto seria original por fundar-se em bases extraliterárias e pelo fato de ter sido escrito pela primeira vez. A expressão "conto direto" também poderia ser entendida como uma "transcrição direta" pelo fato

${ }^{1}$ A partir dos ensaios sobre tradução do jornal Crítica, Borges deslocará o valor estético da tradução para o tradutor. Para uma análise pormenorizada da seção "Etcétera", cf. GROTTO, 2012. 
de o autor implícito reproduzir a fala do narrador. Mas no mesmo prólogo de 1954, J.L.B. desfaz essa impressão, realçando o artifício de sua escrita. Ele, e não o narrador, escolheu as palavras do texto. Algumas delas cultas, porque o homem originário dos bairros periféricos almeja a "finura" e porque não é o "Compadre" ideal e platônico:

En su texto [el de "Hombre de la esquina rosada"], que es de entonación orillera, se notará que he intercalado algunas palabras cultas: vísceras, conversiones, etcétera. Lo hice, porque el compadre aspira a la finura, o (esta razón excluye la otra, pero es quizá verdadera) porque los compadres son individuos y no hablan siempre como el Compadre, que es una figura platónica.

Além da linguagem, outro artifício - que não se repete nos contos do núcleo "Historia universal de la infamia" - pode ser destacado em "Hombre de la esquina rosada". Trata-se do final imprevisto. No último parágrafo e numa só frase, o narrador anônimo nomeia um ouvinte chamado "Borges" e, ao mesmo tempo, assume-se protagonista do crime que vinha contando. A história cobra sua maior força nesse desenlace, dada a emoção que provoca no leitor, e muito provavelmente nesse Borges ficcionalizado, cara a cara com o personagem principal, até então mero testemunha de uma recusa a duelo seguida de assassinato.

Entretanto, esse Borges para sempre incrustado no mundo da ficção não era tudo. É só em 1970 que um J.L.B. mais satisfeito diz ter encontrado sua voz, graças ao abandono dos finais imprevisíveis e do estilo barroco que elogiara em 1954, com todos os seus artifícios, como as variações e as novidades. Um ano antes, aliás, em 1969, o barroco transformara-se, num prefácio a Fervor de Buenos Aires, também no eufemismo utilizado por Borges para referir-se aos "excessos" do ultraísmo, da vanguarda e do criollismo.

O texto de 1970 no qual J.L.B. reprova os finais imprevisíveis e seu próprio barroquismo era o prólogo de El informe de Brodie. Nele, Borges estabelecia outro diálogo com o prólogo de 1954 da Historia universal de la infamia ao retomar a expressão "conto direto", empregada para caracterizar "Hombre de la esquina rosada". Conservava, entretanto, apenas um de seus sentidos: o de uma narração fundada em bases extraliterárias. Ora, num dos "contos diretos" de El informe de Brodie - "Historia de Rosendo Juárez" -, o autor implícito escuta uma versão distinta de "Hombre de la esquina rosada", narrada segundo outro ponto de vista. Este é um dos motivos que justifica a renúncia ao sentido de narração primigênia. 
Quer seja artificiosa e barroca, quer seja natural e intuitiva, é importante notar que para os Borges de 1954 e de 1970 a "manera directa" de narrar relaciona-se com a voz autoral. Nesse sentido, parece contraditório que em "Hombre de la esquina rosada" e em "Historia de Rosendo Juárez" o autor implícito permaneça em silêncio. Ainda mais radical, ele nem chega a ser nomeado na versão de 1970.

No começo deste ensaio, abordou-se a humildade e a modéstia do eu lírico do poema "Mis libros" de La rosa profunda, que se retira do papel de escritor e almeja ser reconhecido enquanto leitor. No conto de 1970, ocorre uma substituição desse tipo, mas o escritor, em vez de denominar-se leitor, situa-se em outra categoria da recepção: a de ouvinte. No prólogo de El informe de Brodie, Borges recupera a expressão "conto direto", talvez no intuito de uniformizar retroativamente a autoimagem que finalmente julgou mais adequada: modesto a ponto de nivelar-se com um leitor ou com um ouvinte.

No conto de 1970, "Borges" pode ser identificado somente porque o personagem-narrador, Rosendo Juárez, recorda uma amizade que tiveram em comum (Paredes), e a existência de uma versão escrita da história que pretende recontar. Abaixo estão as palavras que Rosendo Juárez dirige ao autor implícito:

- Usted no me conoce más que de mentas, pero usted me es conocido, señor. Soy Rosendo Juárez. El finado Paredes le habrá hablado de mí. El viejo tenía sus cosas; le gustaba mentir, no para engañar, sino para divertir a la gente. Ahora que no tenemos nada que hacer, le voy a contar lo que de veras ocurrió aquella noche. La noche que lo mataron al Corralero. Usted, señor, ha puesto lo sucedido en una novela, que yo no soy capacitado para apreciar, pero quiero que sepa la verdad sobre esos infundios (BORGES, 2010, p. 711).

Rosendo é um ex-"compadrito" que sabe muito bem quem é Borges: um escritor que no passado fora influenciado por Nicolás Paredes, contador que divertia e "criollo rumboso" / "nativo esplêndido" (BORGES, 2009, p. 226), mas descomprometido com a verdade. Entretanto, é provável que a escassa educação formal de Rosendo o tornasse incapaz de apreciar o trabalho de seu interlocutor, daí o consequente engano que comete com relação ao gênero empregado em "Hombre de la esquina rosada", chamando-o "novela" / "romance", em vez de conto.

Entre este "conto direto" de El informe de Brodie e o "conto direto" de Historia universal há, entretanto, uma distância concernente ao silêncio do autor implícito. Afinal, em seu primeiro livro de ficção, Borges desponta 
para ocupar um lugar de extremo prestígio, não só frente a seu interlocutor, mas dentro do gênero conto. Embora não tenha voz, atrai e fixa a atenção do personagem-narrador. Isso se concretiza justo no final, segundo Edgar Allan Poe, o lugar do conto reservado para o efeito único, onde explode a energia acumulada ao longo do texto e onde há uma conviç̧ão máxima.

Essa concepção, claro está, foi rejeitada por Borges no prólogo de 1970 a El informe de Brodie, quando opôs o "conto direto" a uma operação da inteligência. Entre outros motivos, é nesse sentido que em 1980 recriminava "Hombre de la esquina rosada" por suas soluções cerebrais: "Está demasiado hecho", dizia (RODRÍGUEZ MONEGAL, 1980, p. 213). Mas em 1935 e na reedição de 1954, o monólogo de interpelação centrípeta de "Hombre de la esquina rosada", dirigido inicialmente a um público ("ustedes"), por vezes restringido a um "señor" e terminando, finalmente, por revelar "Borges”, não é uma modulação calculada ao acaso. A seguir, pode-se ler as cinco frases que perfazem o caminho de interlocução do personagem-narrador. A última corresponde à frase final do conto:
1) A ustedes, claro que les falta la debida experiencia para reconocer ese nombre, pero Rosendo Juárez era el Pegador, era de los que pisaban más fuerte por Villa Santa Rita.
2) Se murió, señor, y digo que hay años que ni pienso en ella, pero había que verla en sus días, con esos ojos.
3) Recordarán ustedes aquella ventana alargada por la que pasó en un brillo el puñal.
4) Aprovechadores, señor, que así se le animaban a un pobre difunto indefenso, después que lo arregló otro más hombre.
5) Entonces, Borges, volví a sacar el cuchillo corto y filoso que yo sabía cargar aquí, en el chaleco, junto al sobaco izquierdo, y le pegué otra revisada despacio, y estaba como nuevo, inocente, y no quedaba ni un rastrito de sangre (BORGES, 2009, p. 628, 632, 633). ${ }^{2}$

Como se estivesse numa roda, o narrador de "Hombre de la esquina rosada”, cônscio de alguma superioridade, tem em vista um público que considera inexperiente na primeira frase e ligeiramente desatento na terceira. Uma vez ou outra - como na segunda e quarta frases - detém-se num dos ouvintes, procurando transmitir sua estupefação. A surpresa do final vai, no entanto, dedicada a um único interlocutor, no qual é provável

${ }^{2}$ Os itálicos são meus. Em outra frase aparece um "usté" que não acrescento ao que chamo de caminho de interlocução porque cumpre sobretudo uma função impessoal: "Era un local que usté lo divisaba de lejos" (BORGES, 2009, p. 628). 
que divise o deleite de sua narração. Mais do que o ouvinte que resta, Borges é o ouvinte ideal, de antemão conhecido, e digno de ser nomeado.

Se frente ao leitor, o narrador, protagonista e criminoso permanece anônimo, sua identidade não é mistério para uns poucos, além de Borges. Dois anonimatos são, portanto, desfeitos nesse conto. O do narrador, apenas parcialmente, e o do ouvinte predileto e autor implícito, desvelado não só para a roda de ouvintes, mas para qualquer leitor de "Hombre de la esquina rosada". "Borges", testemunha da narração, empresta realidade ao conto e torna-se depositário de uma narrativa oral de cuchilleros/ "navalhistas". Simultaneamente, outro campo de força ainda atua na revelação desse nome, pois desse conto em diante a mitificação do autor será praticada às claras e, para sempre, o Borges escritor será o Borges ficcional.

As duas identidades reveladas - a do narrador e a do ouvinte/autor - correspondem a uma duplicidade de sentidos que percorre todo o conto: um para a história do narrador e outro mais sutil, responsável por cifrar a assimilação experimentada pelo autor implícito, pois, ao menos figurativamente, o destino oculto e revelado do narrador é também o do Borges ficcional. "Hombre de la esquina rosada" rememora, afinal, o momento em que um qualquer ganha fama, coragem e hombridade. Para além do abandono do anonimato, é uma história sobre a superação da insignificância. Nascido e criado "entre las flores de sapo y las osamentas" / "entre as flores de sapo e os ossamentos", o narrador se sentia "yuyo de las orillas" / "mato das margens" (BORGES, 2009, p. 631).

Quando Rosendo recusa o duelo com o Corralero, todos o têm por covarde. Isso instiga o narrador, pesaroso com a descoberta de que "no éramos naides" / "não éramos ninguéns/de nada" (2009, p. 630), a tomar parte na história com a finalidade de remediar a desonra a que todos assistiram. Assassina, então, o Corralero, acreditando resgatar a valentia presumida de um "guapo" / "valentão", e acabando por justificar-se perante si e como homem.

É, esta, pois, a lição que escuta o Borges ficcionalizado, absorvendo o caminho da autoconfiança e da fama através da infâmia. Os senões, ironias e ambiguidades destilados nos prólogos da Historia universal já prefiguravam esse percurso da máscara autoral que deixa o papel de principiante para domesticar o olhar de um "guapo", do qual também conquista o devido respeito. Ombro a ombro com o narrador, o reconhecimento de Borges ocorre no texto que, num livro dividido em cinco partes, ocupa a posição central; o único, além disso, cujo tema 
é exclusivamente argentino. O conto representa, desse modo, uma declaração de argentinidade e uma identificação com a cultura marginal: recorde-se, nesse sentido, que "Hombre de la esquina rosada" também se encontra numa das margens ou limiares da "Historia universal de la infamia”, a seção que empresta seu título ao livro. Apesar disso, sua importância não é menor porque inclui a esquina do armazém portenho descrita por um poeta menor como Carriego, além do assassinato de um conhecido do autor dentro do universalmente infame. Daí, quem sabe, o comentário do prólogo de 1954, sublinhando seu "éxito singular y un poco misterioso".

\section{A VOZ NARRATIVA DAS HISTÓRIAS INFAMES E SUPER- -HISTÓRICAS}

Em grande medida, oautor implícito de Historia universal éconstruído por meio da releitura e do embate com a tradição livresca. Mesmo quando, supostamente, em "Hombre de la esquina rosada”, reelabora-se a cultura marginal e oral do subúrbio de Buenos Aires, os livros permeiam a formulação da imagem do Borges ouvinte, daí a presença de Evaristo Carriego e da "biografia" homônima no prólogo de 1935. É também desde as margens da Historia universal, sempre textuais, que a imagem de Borges se agiganta dentro do cânone literário. A bibliografia oferecida como prova de uma seleção pessoal, o prestígio atribuído ao tradutor e a demonstração culta dos prólogos, com catorze autores citados direta ou indiretamente, erigem uma figura incontornável. Além de escritor, é crítico, leitor, ouvinte, tradutor e erudito.

Essa notável autopropaganda, realizada com base na intertextualidade tramada no interior da Historia universal de la infamia, e desde seus limiares, faz com que a voz do autor ressoe em primeiro plano. Existe, assim, uma percepção de que o mais importante não está nas obras citadas, no enredo, nos personagens ou no sentido veiculado pela obra, mas nessa voz, que ecoa para além da forma e da estrutura.

\section{Os espelhos parciais de Borges, escritor portenho e universal}

O narrador das histórias infames se aproxima do escritor Borges porque sabe que escreve. Agente da escrita, discute a tarefa que se impôs 
e tem consciência de que organiza o conjunto de uma "História universal". No interior de cada uma das narrações, avalia a contribuição de certos efeitos, identifica momentos marcantes, julga prosseguir por um lado ou outro no desenvolvimento da ação. Conhece, além disso, seu papel de dar a pensar e de emocionar por meio de instrumentos estéticos. Entretanto, a falta de uma identificação explícita entre o escritor e o narrador autoriza liberdades contraditórias, mas não excludentes. Por um lado, o narrador associa-se aos anseios, ao sentido moral, estético, ideológico e patriótico do escritor Borges. Por outro, a evidente inscrição ficcional do livro cujo insólito parâmetro é a infâmia - corrói as linhas que poderiam unir as figuras do narrador e do autor real. É essa a instabilidade sem cessar praticada em Historia universal, que fia e desfia a voz autoral.

No trecho abaixo, famoso parágrafo de abertura do conto "El atroz redentor Lazarus Morell" e da própria seção "Historia universal de la infamia”, o narrador enumera as consequências da decisão do padre Bartolomé de las Casas de substituir a escravidão dos índios pela dos negros. Um “debemos" entra em cena. A fórmula majestática aproxima o narrador do leitor, supondo que este também é testemunha das mudanças desencadeadas pelo missionário espanhol. Arrolam-se, então, dezoito efeitos, exagerados, dramatizados e temporalmente longínquos. Todos se vinculam à América, sobretudo aos Estados Unidos, ao Uruguai e à Argentina. Predomina, contudo, o ponto de vista específico do Río de la Plata. Por isso Pedro Figari, que pintou negros em suas práticas cotidianas - Duelo criollo, Pericón bajo los naranjos, Picnic de esclavos, Barrio de negros, Llevando al muerto, Las gracias de Eusebita, Lavanderas, uma série de "Candombes" e de "Bailes en el campo" -, e Vicente Rossi, autor de Cosas de negros, são chamados "orientais", segundo o gentílico que se usava na época, em vez de "uruguayos". Numa das transformações sofridas em Cuba, o tango, especialmente difundido na Argentina, torna-se o filho da habanera:

En 1517 el P. Bartolomé de las Casas tuvo mucha lástima de los indios que se extenuaban en los laboriosos infiernos de las minas de oro antillanas, y propuso al emperador Carlos V la importación de negros que se extenuaran en los laboriosos infiernos de las minas de oro antillanas. A esa curiosa variación de un filántropo debemos infinitos hechos: los blues de Handy, el éxito logrado en París por el pintor doctor oriental D. Pedro Figari, la buena prosa cimarrona del también oriental D. Vicente Rossi, el tamaño mitológico de Abraham Lincoln, los quinientos mil muertos de la Guerra de Secesión, los tres mil trescientos millones gastados en pensiones militares, la estatua del imaginario Falucho, la admisión del verbo linchar en la decimotercera edición del Diccionario de 
la Academia, el impetuoso film Aleluya, la fornida carga a la bayoneta llevada por Soler al frente de sus Pardos y Morenos en el Cerrito, la gracia de la señorita de Tal, el moreno que asesinó Martín Fierro, la deplorable rumba El Manisero, el napoleonismo arrestado y encalabozado de Toussaint Louverture, la cruz y la serpiente en Haití, la sangre de las cabras degolladas por el machete del papaloi, la habanera madre del tango, el candombe (BORGES, 2009, p. 597).

Apesar de, na visão do narrador, os eventos listados terem um valor semelhante, três deles são exclusivamente argentinos. Somados com a perspectiva do Río de la Plata, esses detalhes parecem dizer mais sobre o escritor do que sobre o capricho do padre Bartolomé de las Casas. Sylvia Molloy (1979, p. 34) considera-os parte de uma "mitologia caseira". O primeiro evento argentino é verídico, embora aos olhos do narrador pareça ficção: a "estátua do imaginário Falucho" encontra-se desde 1923 num dos bairros tematizados por Borges, Palermo. Homenageia um escravo negro, fuzilado em 1824 por ter-se negado a prestar honras à bandeira espanhola. O segundo é histórico: a "fornida carga da baioneta levada por Soler à frente de seus Pardos e Morenos em Cerrito" refere-se à tropa de soldados negros e mulatos comandada pelo argentino Miguel Estanislao Soler, herói da guerra de independência, colaborador de San Martín e vencedor do exército espanhol em 1812, numa colina chamada Cerrito, em Montevidéu. O terceiro é literário: o "moreno que assassinou Martín Fierro" recupera a parte final do longo poema de José Hernández, La vuelta de Martín Fierro, quando, hipoteticamente, Moreno vinga a morte do irmão, assassinado pelo protagonista no capítulo sete de El gaucho Martín Fierro.

De modo geral, a crítica não compartilha a interpretação de que houve um duelo do qual Martín Fierro saiu morto, tal como se garante nesse trecho de Historia universal e, futuramente, na reinterpretação oferecida pelo conto "El fin" e no pós-escrito de 1956 ao prefácio de Ficciones (2009, p. 483). Em 1935, portanto, e como notamos desde os prólogos de Historia universal de la infamia, Borges já escrevia e inscrevia suas próprias leituras. No caso desta última, Beatriz Sarlo (2003) observou, com a acuidade que caracteriza seus ensaios, que se tratava, para Borges, de diferenciar-se do modernismo de Leopoldo Lugones e afirmar sua postura vanguardista e pessoal. Ao reler esse mito fundador da literatura argentina segundo outro ponto de vista, chamaria a atenção para esse herói moralmente reprovável, que insulta e briga, que é um assassino, um desertor e um proscrito.

Na frase de abertura de outro conto, "El impostor inverosímil Tom Castro", o narrador mantém o ponto de vista argentino. Elege, entre algumas opções, o nome que vincula seu personagem tanto com algumas 
cidades do Chile - Talcahuano, Santiago do Chile e Valparaíso - quanto com seu próprio país. A Argentina, no entanto, parece a tal ponto subentendida que merece somente a menção "estas tierras". Segundo o narrador, o homem real esteve nas ruas e casas do Chile, mas na qualidade "de fantasma e de passatempo", ou, em outras palavras, na qualidade de mito ficcional, é a "estas terras" que retorna:

Ese nombre le doy porque bajo ese nombre lo conocieron por calles y por casas de Talcahuano, de Santiago de Chile y de Valparaíso, hacia 1850 , y es justo que lo asuma otra vez, ahora que retorna a estas tierras - siquiera en calidad de mero fantasma y de pasatiempo del sábado (BORGES, 2009, p. 603).

Nesse conto, Borges contorna uma adversidade portenha que considerava latente. No ensaio "El tamaño de mi esperanza", queixava-se da falta de mitos da cidade de Buenos Aires: "No hay leyenda en nuestra tierra y ni un solo fantasma camina por nuestras calles. Ése es nuestro baldón” (BORGES, 2008, p. 16). Finalmente, portanto, o "inverossímil Tom Castro" caminha pelas ruas de Buenos Aires. Jorge Luis Borges vai, discretamente, a seu lado.

É o que se pode depreender da nota de rodapé que acompanha, no excerto acima de "El impostor inverosímil Tom Castro", a expressão "pasatiempo del sábado": "Esta metáfora [pasatiempo del sábado] me sirve para recordar al lector que estas biografías infames aparecieron en el suplemento sabático de un diario de la tarde".

Nesta nota, a primeira pessoa mantém-se, mas o "eu" transforma-se ao simular um desvelamento da identidade, reservado ao curioso que baixou os olhos até as letras miúdas do rodapé. A nota tem pelo menos duas funções: sugerir a utilidade do texto literário na constituição da figura do autor implícito, daí uma metáfora que lhe "serve" e, sobretudo, emparelhar a imagem do narrador desse livro com a do escritor Jorge Luis Borges. É esse talvez o principal motivo para que se repita, num texto tão curto, a frequência semanal da publicação - "sábado" e "sabático" fazendo coincidir a voz narrativa do corpo do texto com a voz do escritor no rodapé.

O escritor (do rodapé) interfere na ficção, e o narrador (do livro) interfere na observação do escritor. Há de se convir que uma nota explicativa convencional não esquivaria três informações elementares: o título desse suplemento que era "passatempo do sábado", "Revista Multicolor de los sábados", o "jornal da tarde” que o distribuía, chamado 
Crítica, e o local de publicação, "estas tierras" de Buenos Aires. Como na alusão ao livro Evaristo Carriego do prólogo de 1935, o autor-narrador de Historia universal reclama um leitor que acompanhe seu percurso, dentro e fora dos livros.

Em "El proveedor de iniquidades Monk Eastman”, as subpartes iniciais "Los de esta América" e "Los de la otra" opõem, respectivamente, Argentina e Estados Unidos. O "esta” e o "nosso", de acordo com Daniel Balderston (2003, p. 32), têm o inesperado eco do José Martí de Nuestra América. As subpartes separam dois perfis de brigão, dois tipos de briga, dois estereótipos de coragem e dois modos de ser infame. Em "Los de esta América”, transcrito logo abaixo, o narrador enfatiza que o lugar de escrita, publicação e recepção da Historia universal de la infamia é a Argentina, retratada segundo parâmetros exclusivamente estéticos:

Perfilados bien por un fondo de paredes celestes o de cielo alto, dos compadritos envainados en seria ropa negra bailan sobre zapatos de mujer un baile gravísimo, que es el de los cuchillos parejos, hasta que de una oreja salta un clavel porque el cuchillo ha entrado en un hombre, que cierra con su muerte horizontal el baile sin música. Resignado, el otro se acomoda el chambergo y consagra su vejez a la narración de ese duelo tan limpio. Ésa es la historia detallada y total de nuestro malevaje. La de los hombres de pelea de Nueva York es más vertiginosa y más torpe (BORGES, 2009, p. 611).

Numa parede imaterial de tanto azul, o narrador identifica o perfil de dois homens. Parecem movidos pelo tango, música grave que num conhecido poema de Carriego é dançada por homens do subúrbio. ${ }^{3}$ Surgem duas facas de igual medida e um deles é ferido de morte. O outro, como no conto "Hombre de la esquina rosada", passará a velhice recordando esse duelo, tão limpo que no lugar do sangue brota um cravo vermelho. ${ }^{4}$ Essa história de "compadritos", diz o narrador com outro argentinismo, é a "de nuestro malevaje”, ou seja, a dos meliantes das aforas de Buenos Aires.

3 Leia-se a descrição do poema "El alma del suburbio" de Carriego (1946): "En la calle la buena gente derrocha/ sus guarangos decires más lisonjeros,/ porque al compás de un tango que es 'La morocha',/ lucen ágiles cortes dos orilleros”.

${ }^{4}$ Mais uma vez, como em Carriego (1946). No poema "De la tregua”: “isobre el rojo clavel de mis crueldades/ sangrarán mi perdón tus azucenas!”. Em “Imágenes del pecado”: "Fue la hora en que cayeron/ deshojados los claveles, / que, al sangrar las castidades/ en los tálamos crueles,/ los augurios se regaron con los filtros de la/ Vida”. Cf., no mesmo livro, o poema "El clavel". 
Buenos Aires e sua mitologia suburbana, aliás, propiciam a Borges o contraste necessário para enveredar pela história da outra América, de mais coragem e violência. Leitor erudito e por vezes tradutor, o autor pode discorrer sobre seu país, mas também sobre os Estados Unidos, o Turquistão, a China ou o Japão, cenários dos contos da seção "Historia universal de la infamia”. Futuramente, no ensaio "El escritor argentino y la tradición", Borges reivindicará claramente que seu "patrimônio" é o universo. Esse universo, diga-se de passagem, queé pouco ou nada acessível para um leitor argentino médio. O cosmopolitismo do autor, como vimos antes, já inspirara as traduções de "Etcétera" e a série decorrente do sentimento de pena do padre Bartolomé de las Casas, responsável por englobar do blues americano às novidades plásticas de Paris, da entrada de um novo verbo no Diccionario de la Real Academia Española ao líder haitiano Toussaint Louverture.

\section{REFERÊNCIAS BIBLIOGRÁFICAS}

BALDERSTON, Daniel. Borges and The Gangs of New York. Variaciones Borges. Pittsburgh, University of Pittsburgh, n. 16, 2003.

BOOTH, Wayne. Distance and Point-of-View: An Essay in Classification. In: Essentials of the Theory of Fiction (org.: Hoffman e Murphy). 2. ed. Durham, North Carolina: Duke University Press, 1996.

BORGES, Jorge Luis. El tamaño de mi esperanza. Madri: Alianza, 2008.

BORGES, Jorge Luis. Obras completas I. Edición crítica anotada por Rolando Costa Picazo e Irma Zangara. Buenos Aires: Emecé, 2009.

BORGES, Jorge Luis. Obras completas II. Edición crítica anotada por Rolando Costa Picazo. Buenos Aires: Emecé, 2010.

BORGES, Jorge Luis. Obras completas III. Edición crítica de Rolando Costa Picazo. Buenos Aires: Emecé, 2011.

BORGES, Jorge Luis. “Ultraísmo”. In: . Textos recobrados 1919-1929. Buenos Aires: Emecé, 1997.

CARRIEGO, Evaristo. Misas herejes: la canción del barrio. Buenos Aires: Tor, 1946.

GENETTE, Gérard. Palimpsestes. Paris: Seuil, 1992.

GENETTE, Gérard. Seuils. Paris: Seuil, 1987. 


$$
\text { Grotto - } 217
$$

GROTTO, Livia. Jorge Luis Borges e "Etcétera". Tradterm. São Paulo, CITRAT, USP, v. 2o, 2012.

MOLLOY, Sylvia. Las letras de Borges. Buenos Aires: Sudamericana, 1979.

RODRÍGUEZ MONEGAL, Emir. Borges por él mismo. Caracas: Monte Ávila, 1980.

SARLO, Beatriz. Tradición y conflictos. In: . Borges, un escritor en las orillas. Buenos Aires: Seix Barral, 2003. 